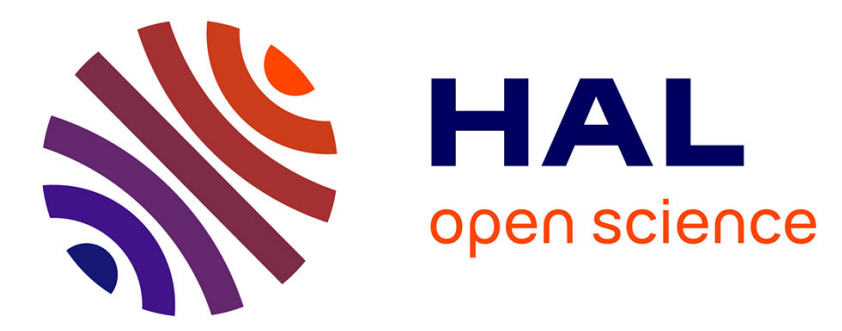

\title{
Startup valuation by venture capitalists: an empirical study
}

\author{
Tarek Miloud, Arild Aspelund, Mathieu Cabrol
}

\section{To cite this version:}

Tarek Miloud, Arild Aspelund, Mathieu Cabrol. Startup valuation by venture capitalists: an empirical study. Venture Capital, 2012, 14 (2-3), pp.151-174. 10.1080/13691066.2012.667907 . hal-00951664

\section{HAL Id: hal-00951664 https://hal.science/hal-00951664}

Submitted on 25 Feb 2014

HAL is a multi-disciplinary open access archive for the deposit and dissemination of scientific research documents, whether they are published or not. The documents may come from teaching and research institutions in France or abroad, or from public or private research centers.
L'archive ouverte pluridisciplinaire HAL, est destinée au dépôt et à la diffusion de documents scientifiques de niveau recherche, publiés ou non, émanant des établissements d'enseignement et de recherche français ou étrangers, des laboratoires publics ou privés. 


\title{
Startup valuation by venture capitalists: an empirical study
}

\author{
Tarek Miloud*, Arild Aspelund and Mathieu Cabrol \\ Department of Finance, Chambery Business School, Savoie Technolac, \\ Le Bourget du Lac Cedex, France
}

(Received 2 March 2011; final version received 14 February 2012)

\begin{abstract}
How to value a new venture is critical in entrepreneurial financing. This article develops an integrated theoretical framework to examine whether venture capitalists' valuation of a new venture can be explained by factors identified in the strategy theories as important to firm performance. Empirical results from the analyses of 184 rounds of early-stage venture capital investments in 102 new ventures support the central proposition that venture capitalists do take into consideration those factors that are important to firm performance in their valuation of new ventures. More specifically, this article finds that attractiveness of the industry, the quality of the founder and top management team, as well as external relationships of a new venture significantly and positively affect its valuation by venture capitalists when it seeks venture capital financing in its early stages of development. These empirical findings help to establish an initial linkage between the well-developed theories in strategic management and underresearched venture capital valuation practice. It brings more theoretical rigor to the venture capital investment literature by introducing a systematic approach to identify and measure factors important to new venture valuation. It explores a possibility to develop a supplementary method to value an early-stage new venture when extant valuation methods fail to yield consistent results because these methods require accounting information that a new venture typically cannot provide.
\end{abstract}

Keywords: startup valuation; venture capital; entrepreneurial finance

\section{Introduction}

How should an entrepreneur value his startup company when he seeks equity financing from a venture capitalist? And on the other side of the table, how do venture capitalists value a prospective entrepreneurial firm when they make an investment decision? These are two central questions that entrepreneurs and venture capitalists have been struggling with for generations. Yet, currently there is no systematic answer to these two important questions. To identify good solutions are essential for both the entrepreneur and the investor for many reasons.

For the venture capitalists, the valuation is important because the value of the company determines the proportion of the shares they receive in return for their investments, guides the overall profitability of their fund and thus also affects their relationship with their fund providers. Likewise, the valuation is important for the

*Corresponding author. Email: tmiloud@gmail.com 


\section{T. Miloud et al.}

entrepreneur as it governs the motivation and sets a value to the efforts and resources he puts into his new venture. More than that, research has shown that the valuation is important because it aligns the ambitions of the entrepreneur and investor, helps structure and assure a fair treatment (Clercq et al. 2006) and reduces the sources of potential conflict between the entrepreneur and the investor (Zacharakis, Erikson, and Bradley 2010). The seminal venture capital study by Tyebjee and Bruno (1984) shows that the venture capital investment follows a somewhat well-defined process starting from deal origination and ending at the exit of investment. In this staged process, the valuation of an entrepreneurial firm is one of the most important and challenging issues facing both entrepreneurs and venture capitalists. Tyebjee and Bruno (1984) maintain that establishing the price of venture capital is the heart of any negotiation between the founders of the venture and potential investors.

According to mainstream finance theory, the economic value of any investment is the present value of its future cash flows (Brealey, Myers, and Allen 2007). Simple as it is, this axiom definition of economic value presents a challenge to financial valuation methods when applied to valuating a new venture. The commonly used valuation techniques in corporate finance (e.g. discounted cash flow method, earning multiple method and net asset method, etc.) depend on strict assumptions and require information that new ventures typically cannot provide (such as accounting information). Hence, their applicability is severely limited in valuating early-stage new ventures and both venture capitalists and entrepreneurs are frustrated by huge variance of valuations computed from the extant methods for exactly the same new venture. Practically, the practice of startup valuation by venture capitalists remains a 'guess' and 'alchemy'.

The need for more rigorous research in venture capital investment, in general, has also been recognized by many prominent entrepreneurship scholars. For example, Barry $(1994,3)$ points out that 'in spite of the intriguing issues in venture capital finance, relatively little has been published on this subject in the most influential finance journals'. Furthermore, some studies (see, e.g. Waldron and Hubbard 1991; Hall and Hofer 1993; Gompers 1999) review studies of startup valuation in both the entrepreneurship and corporate finance literature and find that there is a gap in the extant literature. More recently, several studies in the entrepreneurial finance literature have investigated the factors that influence the investment process. For example, Silva (2004) studies venture capitalists' (VCs) decision-making and finds that their attention is focused on the entrepreneur, the business idea, its sustainable advantages and growth potential. According to his study, the financial projections of the prospect do not seem to play a major role in the selection of early-stage projects. Levie and Gimmon (2008) explain why there is a suboptimal evaluation by investors of the human capital of first-time high tech venture founders - they support the idea that there is a gap between in-use and espouse investment criteria, and extensive use of gut feeling in decision-making.

These studies show that there is a great need for a better understanding of startup valuation for both practical and theoretical reasons. Venture capital investment in general, valuation in particular, is a very important entrepreneurial phenomenon and we do not know sufficiently about this critical aspect of the entrepreneurial process. This study aims to contribute by performing a quantitative empirical investigation of the influence of non-financial, strategic factors on the actual valuation of French startup firms. We identify the most influential factors for firm performance from three different but complementary strategic perspectives - industry organization economics, 
resource-based view and network theory for our analysis. The result is the first step on an alternative route to startup valuation based on strategic analysis rather than manipulation of 'imaginary' numbers.

\section{Theoretical framework and hypotheses}

According to the finance literature (Brealey, Myers, and Allen 2007), the valuation process of the firm is complex because of the diversity of factors that come into play. It goes far beyond pure financial considerations of balance sheets, income statements and the financial forecasts. For example, industry characteristics, such as intensity of rivalry, entry and exit barriers, and firm characteristics, such as its development stage and competitiveness, are qualitative rather than quantitative factors which significantly influence firm value. To gain insight into these factors for valuation purposes, we need to look to other theories than finance for directions. In particular, the entrepreneurship and strategic management literatures provide us with considerable insight on the antecedents of firm performance and how value is created in an entrepreneurial process.

Over the past half century, several theories have been developed to explain and predict firm performance and value creation. Three of these are of particular relevance to our startup valuation context: (i) industry organization economics, (ii) resource-based view and (iii) network theory. Each of these theories approaches the central issue (firm performance) from a different perspective. The industry organization tradition focuses on the structure of the market in which firms compete and highlights the importance of industrial structure in determining firm performance. The resource-based view conceptualizes the firm as a bundle of valuable resources and stresses the importance of internal resources in predicting firm performance. Bridging the two ends of the spectrum, network theory underscores how the external relationships of a firm channel resource flow and shape its strategies, and hence impact its performance. By putting them together, we seek to develop an integrated framework to estimate the value of a startup.

This theoretical framework suggests that firm resources, external ties and market opportunities jointly determine firm performance, which is unobservable ex ante, but is the theoretical base for firm value, upon which venture capitalists and entrepreneurs negotiate their individual estimates of the valuation. Through negotiations between the venture capitalists and the entrepreneur over their estimations of future economic performance of the startup, their estimations converge and the deal is priced. The logic of this approach is straightforward. The constructs (and related variables) in the framework have been found important to firm performance in the strategy literature. If financial methods relying on an estimated future cash flow can come up with a valuation for a new venture, the strategic management approach developed here can achieve similar (or better) results when future cash flow is difficult to estimate but input factors that influence future cash flow can be objectively measured. Obviously, when it is difficult to value a subject based on output (future cash flows), pricing it based on inputs (entrepreneur, industry attractiveness, etc.) may be a better alternative than 'pure guess'. As the first exploratory study applying strategy theories to startup valuation, this study may not completely solve the problem, but based on accumulated knowledge of the strategy field over the past half century, empirical findings in new venture performance and venture capital investment literature, and discussions with entrepreneurs and venture 
capitalists, there are substantial justifications that the model will perform well. According to Dittmann, Maug, and Kemper (2004), the use of multiple valuation methods significantly reduces the failure rate of funding agreements between venture capitalists and entrepreneurs.

The framework also has high internal consistency. A fundamental similarity between industry organization economics and the resource-based view is that both theories assume competition is the ultimate force that drives (or determines) firm performance and any factors - exogenous or endogenous - that impede the competitive forces that are positively related to firm performance. Industry organization theory takes an exogenous perspective by focusing on industry environment in which a firm competes. It identifies the structural conditions under which the competition is likely to be offset and firms can expect to earn abovenormal return. On the other hand, the resource-based view looks inside the 'black box' of firm and highlights the importance of firm-specific (and endogenous) resources. It identifies the characteristics of firm resources that are likely to be immune from competition.

Furthermore, Lee, Lee, and Pennings (2001) have proposed that the resourcebased view should and can be complemented by the network theory. The authors argue that these two perspectives have divergent concerns with the roots of value creation, with resource-based view stressing the internally accumulated resources or capabilities while social capital theory underscores its relational characteristics with external entities. The two theories ought to be synthesized (to study firm performance); since startups should develop firm-specific assets while obtaining complementary external resources through their social networks. Indeed, their results suggest that 'resource-based view and social capital theory need to be simultaneously considered and integrated to better account for entrepreneurial wealth creation'.

In the following, we will draw from the three selected strands of strategic management literature to hypothesize on how central factors in industry organization economics, resource-based view and network theory affect new venture valuation by venture capitalists.

\section{Industry organization and startup valuation}

To examine the effects of industry structure on startup valuation, we focus on two key structural elements from industry organization economics, namely the degree of product differentiation and industry growth rate. We propose that both these factors will influence on firm valuation. Industry profitability and market size will be used as control variables in the empirical test.

\section{Product differentiation}

Caves (1972) argues that product differentiation is one of the most important structural elements of an industry and is positively related to firm performance. Comanor and Wilson (1967) examined consumer goods industries (at three-digit SIC code level) and found that industries with high advertising intensity earn higher rates of return on equity. Porter (1980) argues that industries characterized by low product differentiation require new entrants to attend to cost and capacity considerations, which encourages retaliation against entrants and decreases venture 
performance. Extrapolating from these empirical results on firm performance, we propose:

$H_{1}$ - The degree of product differentiation of an industry is positively related to the valuation of new ventures in this industry.

\section{Industry growth}

Hall and Weiss (1967) find that industry growth rate is positively associated with industry profitability. Porter (1980) argues that because rapid industry growth ensures that incumbents can maintain a strong financial performance, even though a new entrant takes some market share, an entrant into a rapidly growing industry may experience less retaliation. Also, Peltzman (1977) notes that rapid market growth can be beneficial for small firms in lowering costs and enabling such firms to more rapidly assimilate critical skills and knowledge needed for effectively competing in the marketplace. According to Porter (1980), in early stages of the industry life cycle (when industry growth is usually rapid), the costs of entry may be much less than the costs would be for later entrants because of the minimum scale of entry is much smaller. There are initially few entry barriers and seldom dominant actors that can wield monopolistic power. Thus, early entrants may be able to erect entry barriers and gain monopoly profits after they successfully enter the market. Specifically, new entrants entering industries in the introductory stage may realize the benefits of establishing: (i) product standards; (ii) a reputation in the marketplace; (iii) higher customer awareness; (iv) high switching costs; (v) control of scarce resources; (vi) control of distribution channels and (vii) barriers to subsequent entry. Finally, industries in the early stages of development provide an opportunity for new entrants to capture the new demand in markets that have relatively little likelihood of retaliation by established incumbents.

Zider (1998) stresses that the lucrative nature of industry growth has long been chased by practicing venture capitalists, who usually focus on the middle part of the classic industry S-curve (where growth is most rapid). They avoid both the early stage, when technologies are uncertain and market needs are unknown, and the later stages, when competitive shakeouts and consolidations are inevitable and growth rates slow dramatically. Venture capitalist usually can give new ventures in a rapidly growing market higher valuation, just because the market conditions may allow the entrepreneurs to make some mistakes and the investment is less risky compared with similar projects in a low growing market (in which even a small mistake may be vital). Lower risk can usually justify higher valuation. Therefore, we advance the following hypothesis:

$\mathrm{H}_{2}$ - The growth rate of an industry is positively related to the valuation of new ventures in this industry.

\section{Entrepreneurial resources and startup valuation}

For a startup, the entrepreneur and his management team have been reported as the most important resources in various streams of research, including venture capital investment (see, e.g. Tyebjee and Bruno 1984; MacMillan, Siegel, and Narasimha

Subba 1985), entrepreneurial firm performance and survival (see, e.g. Sandberg and 


\section{T. Miloud et al.}

Hofer 1987; Aspelund, Berg-Utby, and Skjevdal 2005) and top management team (TMT) effects (see, e.g. Eisenhardt and Schoonhoven 1996). The heterogeneity of the entrepreneurial team in terms of experience, education or function provides a signal to potential investors and is associated with a higher capital accumulation especially during an initial public offering (IPO) (Zimmerman 2008).

Assumable, as the most important human resources a new venture can have, the founder/entrepreneur plays a critical role in initiating and growing the new business. This fact has been unanimously acknowledged by both academic and venture capital practitioners, and the positive influence associated with the founder/entrepreneur can be found in numerous entrepreneurship studies, e.g. Tyebjee and Bruno (1984), MacMillan, Siegel, and Narasimha Subba (1985), Gimeno, Folta, and Cooper (1997) and Aspelund, Berg-Utby, and Skjevdal (2005). The resource-based perspective suggests a positive relationship between human resources associated with the startup and its valuation.

\section{Entrepreneur}

From a venture capitalists perspective, Timmons (1992) assesses that entrepreneur's 'track record' of 'thorough and proven operating knowledge of the business they intend to launch' is very important. Numerous studies on venture capitalists investment process report that experience (a combination of industry, technical, management, startup experience) is a very important criterion in funding decisions. Three types of experience are considered important in determining this track record:

(1) Industrial (technical and/or market) expertise: Siegel, Siegel, and MacMillan (1993) find that the number of years the entrepreneur has worked in a similar industry significantly and positively related to sales growth. Similar findings are also reported by Gimeno, Folta, and Cooper (1997) and that growth firms tend to be led by entrepreneurs who began their venture based on ideas developed in their previous jobs. Therefore, we propose:

$\mathrm{H}_{3}-\mathrm{A}$ new venture is valued higher if its founder has relevant industry experiences before founding the venture.

(2) Top management experience: The literature on top management experience highlights the skills and knowledge gained through managing a hierarchy of management layers. Its relevance to the performance and valuation of a startup company is that the founder 'has been there before'. Thus, he knows the necessary strategies and organizational structures to grow the tiny new venture to a larger size that requires more sophisticated management infrastructures to support. Empirical findings are consistent with this argument. For example, Gimeno, Folta, and Cooper (1997) find both experiences in both top management and supervisory positions are significantly and positively related to return of investment. Therefore, we propose:

$H_{4}-A$ new venture is valued higher if its founder has previous top management experiences.

(3) Startup or other entrepreneurial experience: Larson and Starr (1993) argue that prior startup (entrepreneurial) experience is assumed to yield a customized set of entrepreneurial skills, a rolodex of network contacts and 
a business reputation which are strategic resources that can be leveraged into future ventures. Rather than 'starting from scratch', experienced entrepreneurs have accumulated the 'wealth, power and legitimacy' which can be used to surmount the traditional obstacles facing new ventures. Muzyka, Birley, and Leleux (1996) confirm that the venture capitalists believe that hand-on direct experience in starting up a new business is an important predictor of new venture success. Lerner (1994) finds that the venture capitalists representation on boards of directors increased by $44 \%$ for firms in which the CEO had no prior experience in running an entrepreneurial firm. Increased board presence of venture capitalists indicates increased needs for both assistance and monitoring, which incurs more costs for the investors. Therefore, we propose:

$H_{5}-A$ new venture is valued higher if its founder has previous startup experiences.

\section{Top management team}

Practitioners have always recognized the importance of the entrepreneurial team and this has also been reflected in the scholarly literature over the past couple of decades. Eisenhardt and Schoonhoven (1990) state that with increasing technological complexity and competition, more and more new ventures are founded by teams rather than single entrepreneurs. According to Muzyka, Birley, and Leleux (1996) and Franke et al. (2008), the completeness of a new venture management team is a major concern to venture capitalists. Two features of the team are of great concern to them, namely the completeness and balance (heterogeneity) of the team. Consistent with the research tradition in the entrepreneurship literature, we propose that the characteristics of the entrepreneurial team will partially determine its valuation.

Solo founder vs. founding team. With the increasing complexity of technologies and competition in the marketplace, 'one-man' shop becomes more and more difficult to survive - simply because no one can have all the necessary skills and knowledge to effectively compete. Eisenhardt and Schoonhoven $(1990,510)$ argue that 'more founders means that there are more people available to do the enormous job of starting a new firm that there is more opportunity for specialization in decisionmaking'. The entrepreneurial team plays a key role in the ventures' valuation by venture capitalists (Franke et al. 2008). According to Tushman and Anderson (1986), entrepreneurial teams help attain strategic maneuvers, including attaining first-mover advantages, forming strategic alliances or developing discontinuous innovations. We suggest that entrepreneurial teams also allow firms greater agility to enter markets quickly and maintain responsiveness to changing market conditions. Members are the repositories of much of the technical and management knowledge, skills, and ability that make up the intangible assets of the firm. Likewise, Eisenhardt and Schoonhoven (1990) found that the size of the founding team is positively related to new venture's sales growth. Therefore, we propose:

$H_{6}-\mathrm{New}$ ventures founded by a team of founders are valued higher than those founded by one founder. 
Completeness of management team. Similarly, the completeness of the management team in a new venture is of importance. In their analysis of the 'verbal protocols' generated from venture capitalists investment decision process, Hall and Hofer (1993) report that 'should have a balanced management team in place' is one of the important criteria to make funding decision. A more quantitative study was reported by Roure and Keeley (1990). In their study of 36 high-tech new ventures funded by venture capitalists, the authors consistently find a significantly positive relationship between the completeness of the management team and four types of measures of return to investment (including internal rates of return to venture capitalists, entrepreneur and other equity holders). The completeness of the management team will not only affect the future performance of the new venture, but also directly affect the valuation of the new venture by potential venture capitalists. For example, a well-known venture capitalist states, 'If we must spend much time to recruit other managers for him (the entrepreneur), we will definitely value him down'. Zider (1998) interprets his statement that a complete management team not only carries more credibility and enhances the chance of success, but also saves time for potential investors, for venture capitalists routinely assist the entrepreneur in hiring. Siegel, Siegel, and MacMillan (1993) found that functionally balanced entrepreneurial teams were positively associated with entrepreneurial firm growth. Therefore, we hypothesize:

$H_{7}-\mathrm{New}$ ventures with a complete management team are valued higher than those without one.

\section{External ties and startup valuation}

Social network perspective has emerged as an important view to understand firm behavior and performance. In the entrepreneurship context, Dubini and Aldrich (1991) emphasize the importance of external ties to understand the start, growth and expansion of new ventures. The more developed the entrepreneurs' network, the easier for them to start and grow their new business. According to Stuart, Hoang, and Hybels (1999), an entrepreneur's network plays an important role in the search for new opportunities, acquisition of resources and gaining legitimacy. First, network facilitates and constrains the entrepreneur in finding lucrative new business opportunities. Second, according to Uzzi (1996), once the opportunity is spotted, the entrepreneurs can leverage their network to pursue the opportunity as the network provides access to resources, usually at a cost substantially lower than that from the open market. Finally, Stuart, Hoang, and Hybels (1999) stress that the network is very helpful when the emerging business requires legitimacy, as more established institutions (and credible individuals) can extend their endorsement to new ventures. This is crucial to overcome the information asymmetry between the entrepreneur and venture capitalists. Zheng, Liu, and George (2010) show in their sample of biotechnology companies that the firm's network influences its performance and therefore, the valuation of the company by venture capital investors - the younger the firm, the greater is this influence. Other benefits from network may include know-how and technology transfer, speed and richness of communication, and trust, cooperation and mutual exchange. Thus, the quantity and quality of the network ties of a startup should be the salient signals to venture capitalists. 


\section{Network size}

Hoang and Antoncic (2002) propose that actors' differential positioning within a network structure has an important impact on resource flows and on entrepreneurial outcomes. According to Gulati (1995), as one of the most important aspects of network structure, network size has been frequently used to describe the position of a focal firm in its network.

Analyses of network size measure the extent to which resources can be accessed at the level of the entrepreneur (Hansen 1995) and the organization (Baum, Calabrese, and Silverman 2000). Deeds and Hill (1996) have found that the larger the network size, the more benefits accrue to the focal firm, subject to the constraints of its capability to effectively manage the network relationships. Stuart, Hoang, and Hybels (1999) find the more strategic alliances a new biotech venture has formed, the sooner it will go public and the more money it will raise in an IPO (higher market valuation). The presence of strategic partners, such as venture capitalists, established pharmaceutical firms and other business firms, all are positively (significant at various levels) related to the speed to and valuation of IPO. Therefore, we propose:

$H_{8}$ - The network size of a new venture is positively related to its valuation by venture capitalists.

\section{Research methodology}

As we are seeking to test proposed causal relationships, we have found a quantitative research approach to be appropriate. In the following, we will describe our research design.

\section{Data sources and case selection}

The venture capital valuation data come from Thomson Financial Securities Data (TFSD), which is the leading source of intelligent information for the world's businesses and professionals, providing customers all types of business alliances, including joint ventures, strategic alliances, licensing agreements, research and development agreements, marketing agreements and supply agreements. According to Lerner (1994), TFSD is the official data collector of the national association of venture capitalists and the most authoritative data source for venture capital investment. Since the valuation data are the outcomes of existing VC valuation methods, one may question whether we can use them as the dependent variable to test a complementary, alternative valuation approach. Our choice is consistent with the finance literature. The central idea is that while each individual investor is not able to estimate the true value of any asset, the mean of their individual estimates is always close to the true value, as long as their estimation is independent and the number of investors is large enough.

Our research focuses on the valuation of early-stage companies because these stages are the most challenging for practitioners and academic researchers. Furthermore, the characteristics of early-stage ventures are relatively easy to identify objectively. In an empirical study of the then widely accepted yet seldom validated 'stages of development' thesis in the entrepreneurship literature, Ruhuka and Young $(1987,165)$ conclude 'strong consensus was found on distinguishing characteristics of ventures in early stages of development ... consensus on developmental 


\section{T. Miloud et al.}

characteristics diminished somewhat in later stages'. For the purpose of this study, early stages include seed stage, startup stage and first stage, consistent with Ruhuka and Young (1987).

The case selection procedures consist of the following steps. The sample firms must (i) have received their early-stage venture capital funding in the period from 1 January 1998 to 31 December 2007; (ii) be less than 5 years old at the time of funding; (iii) be French firms and (iv) not be in the financial and insurance sector. The sample window period covers both 'hot' and 'cold' market and is right after the AMF's (AMF, French Securities Regulator) electronic filling requirement. The above sampling procedures yield a sample of 102 new ventures in 18 industries (defined at five-digit NACE code) in the 7-year period.

\section{Measurements}

The purpose of this research is to attempt to establish the initial theoretical linkage between the strategy variables and new venture valuation, not to maximize the explaining power of the model. While there are different ways to operationalize the variables in the model, we decided to follow the tradition in respective research streams while also acknowledge the constraints imposed by the availability of data.

\section{Dependent variable}

The valuation of a startup is measured by the pre-money valuation, which equals the announced amount of valuation minus the money invested at the financing round - a standard way in the venture capital financing literature among author Gompers (1995). To make sure that the dependent variable is normally distributed, we did a Shapiro-Wilk $W$ test to diagnose a possible deviation from normal distribution. The result shows that the data are not normally distributed. Following Gompers (1995), we did a log transformation of the raw data and used the logarithm of the absolute amount of the pre-money valuation to measure the pre-money valuation of a startup company. After the transformation, the dependent variable becomes normally distributed.

\section{Independent variables}

Industry structural variables. Product differentiation: This has been commonly measured as the advertising intensity ratio, i.e. advertising expenditures divided by sales revenue of an industry. Therefore, following Caves (1972), we measure the degree of product differentiation of an industry as total industry advertising expenditure/total industry sales.

On the other hand, according to Lerner (1995), venture capital investments are known to be biased towards high-tech industries. In high-tech industries, firms aggressively pursue technology superiority and develop products with advanced technological features. Thus, R\&D investment is also an important way for firms to differentiate. In other words, product differentiation may consist of two dimensions: perceptual differentiation and innovative differentiation. Therefore, we also use the average R\&D investment over sales of an industry as a measure of R\&D intensity to capture the innovative differentiation as a complementary measure of product differentiation together with the advertising intensity ratio. We can view the 
advertising intensity ratio as a measure of the perceptual aspect of product differentiation and $R \& D$ intensity ratio as a measure of the innovative aspect of product differentiation.

Industry growth rate: This is measured as the percentage change of the revenue of an industry in year $2\left(T_{2}\right)$ over the revenue of the same industry at year $1\left(T_{1}\right)$.

Entrepreneur/top management team. Industry experience: Any experience involves both qualitative and quantitative dimensions; both matter in any outcome associated with this variable. However, there is no perfect way to measure both aspects of experience. Though a commonly used measure in the literature is to use the number of years the manager has worked in a particular industry, such detailed information is not available for most private firms. Indeed, we could find such detailed experience information for only 23 of the 305 founders in the sample firms. As a crude proxy, we decide to use a dummy variable to measure the founder's industry experience, which is coded ' 1 ' if any of the founders has worked in the same industry before, ' 0 ' otherwise.

Top management experience: Similarly, the management experience of the founder/founding team is measured by a dummy variable, coded ' 1 ' if any of the founder(s) has worked in any executive positions (VP and above position), ' 0 ' otherwise.

Startup experience: We use a dummy variable to indicate the startup experience of the founder and/or founding team, which is coded ' 1 ' when any of the founders has founded a firm before, ' 0 ' otherwise.

Top management team. Following the TMT literature, we define the TMT as the top two tiers of an organization's management. This might include the CEO, chairman, chief operating officer, chief financial officer and the next-highest management tier of a firm, such as President, Senior Vice President and Vice President. Such a definition, which is expected to capture the dominant coalition of the 'upper echelons' of the sample firms, has been applied in other research concerned with strategic actions (Carpenter and Fredrickson 2001) and entrepreneurial firm performance (Roure and Keeley 1990). Thus, we follow this common practice in this study.

Solo founder/founding team: We use a dummy variable to indicate whether a startup in the sample is founded by a single founder or by a team, which is coded ' 1 ' if it is founded by more than one founder and ' 0 ' otherwise. While Eisenhardt and Schoonhoven (1990) use the number of founders of measure founding team size, our interest here is not to ascertain the quantitative effect of the marginal contribution of each founder, but rather the qualitative difference between team-based founding and solo-founder founding in terms of valuation. A qualitative variable is better suited for our research purpose here.

Team completeness: As discussed earlier in this section, depending on the specific situation, key positions in the TMT of a new venture may include: (i) CEO/ President, (ii) VP of marketing/sales/business development, (iii) VP of engineering/ technology, (iv) VP of finance/controller and (v) VP of operation/production/ manufacturing (for manufacturing ventures). We use a dummy variable to capture the completeness of the TMT, which is coded ' 1 ' if all of the above positions were filled at the time of the financing, ' 0 ' otherwise. To make sure the coding is accurate, following Gompers (1999), we also check whether any new positions were filled after the current financing round, as venture capitalists routinely assist in executive recruitment for their portfolio companies. 
Network size. Following the conventional practice in network literature, network size is measured by a direct count of the number of alliance partners a new venture has before the time it received finding from the venture capitalists, which include formal partners for all purposes. There is a concern about possible endogeneity problem on the effect of alliance partners. Our theoretical prediction is that the alliance partners add value to a new venture, thus, venture capitalists should value it accordingly. However, the causality may also run the other way. It may be because a new venture is highly valued by venture capitalists, it attracts alliance partners. Obviously, there is a potential endogeneity problem between alliance partner and firm valuation. By excluding alliances formed after the financing round, we expect this potential problem can be partially mitigated.

\section{Control variables}

Valuating a startup company, or any company, is a complicated task and a myriad of factors may affect the exact valuation. Some of these factors are beyond the scope of our theoretical framework. We need to control for the effects of these factors to avoid making spurious conclusions about our theoretical variables. Thus, we include various control variables in the model, which include financial market, industrial and firm-specific factors. The measurement of these items is straightforward and objective and also follows the established practice in the relevant literature. Further, all measurements (except firm-level control variables) are taken directly from their respective data sources, which have already been calculated.

Previous research finds that movements in the public financial market affect activities in private financial market. For example, Gompers and Lerner (1999) find that every doubling of capital infusion into the public capital market is associated with $26 \%$ increase of average valuation in the venture capital market. To control for this effect, we include the SBF 250 index in the model.

For industry level factors, we include market size and industry profitability as control variables. Market size is measured by the annual revenue of the industry defined at five-digit NACE level, as it is the standard way the Euronext Paris reports the data. While there are several ways to measure profitability, we elect to use the industry return on investment as the measurement. We also control for several firm level variables, namely, firm age and firm development stage at the financing round, and whether the firm is a pure e-commerce firm. Labeled 'Age' in the model, firm age is measured by subtracting its founding date from its financing date and its unit is 'month'. Firm Developmental Stage is coded as a categorical variable, coded ' -1 ' for 'seed stage', '0' for 'startup stage' and ' 1 ' for 'first stage'. We use a dummy variable to code whether a firm is a pure dot.com firm, which is coded ' 1 ' if the firm's main business is mainly conducted through the Internet and ' 0 ' otherwise. Table 1 summarizes the measurements of these variables.

\section{Model estimation and descriptive statistics}

Summarizing the discussions so far, the equation below represents the whole model to be estimated in the empirical analyses: 
Table 1. Summary of variables and measurements.

\begin{tabular}{|c|c|c|}
\hline Variable & Sign & Measurement \\
\hline Pre-money valuation & Dependent variable & $\begin{array}{l}\text { Announced valuation of company - } \\
\text { amount invested }\end{array}$ \\
\hline \multicolumn{3}{|l|}{ Industry structure } \\
\hline Differentiation $\left(H_{1}\right)$ & + & $\begin{array}{l}\text { Industry advertising expenditure/ } \\
\text { industry total sales }\end{array}$ \\
\hline Industry growth $\left(\mathrm{H}_{2}\right)$ & + & $\begin{array}{l}\text { Industry sales in year } T / \text { industry sales } \\
\text { in } T-1\end{array}$ \\
\hline \multicolumn{3}{|r|}{ 1111 1 - 1} \\
\hline Industrial experience $\left(\mathrm{H}_{3}\right)$ & + & $\begin{array}{l}\text { The sum of years the founder(s) } \\
\text { worked in the same industry }\end{array}$ \\
\hline Management experience $\left(H_{4}\right)$ & + & $\begin{array}{l}\text { The sum of number of years } \\
\text { founder(s) worked in top } \\
\text { management positions }\end{array}$ \\
\hline Startup experience $\left(H_{5}\right)$ & + & $\begin{array}{l}\text { Dummy variable, with ' } 1 \text { ' indicating } \\
\text { 'have' and '0' 'no' }\end{array}$ \\
\hline Solo/team dummy $\left(H_{6}\right)$ & + & $\begin{array}{l}\text { Dummy variable, with ' } 1 \text { ' indicating } \\
\text { founded by a team; ' } 0 \text { ' otherwise }\end{array}$ \\
\hline TMT completeness $\left(H_{7}\right)$ & + & $\begin{array}{l}\text { Dummy variable, with ' } 1 \text { ' indicating } \\
\text { all key positions are filled; ' } 0 \text { ' } \\
\text { otherwise }\end{array}$ \\
\hline \multicolumn{3}{|l|}{ Social network } \\
\hline Network size $\left(H_{8}\right)$ & + & $\begin{array}{l}\text { The direct count of the number of } \\
\text { alliance partners }\end{array}$ \\
\hline \multicolumn{3}{|l|}{ Control variables } \\
\hline Market size & & $\begin{array}{l}\text { The total revenue of an industry } \\
\text { defined at five-digit NACE }\end{array}$ \\
\hline Profitability & & $\begin{array}{l}\text { The ROI of an industry defined at } \\
\text { five-digit NACE }\end{array}$ \\
\hline Stock index & & $\begin{array}{l}\text { The close points of the SBF } 250 \text { index } \\
\text { at the financing date }\end{array}$ \\
\hline Firm age & & $\begin{array}{l}\text { The time difference between founding } \\
\text { date and financing date, in unit of } \\
\text { 'month' }\end{array}$ \\
\hline Developmental stage & & $\begin{array}{l}\text { Categorical variable, coded ' }-1 \text { ' for } \\
\text { 'seed stage', '0' for 'startup stage' } \\
\text { and ' } 1 \text { ' for 'first stage' }\end{array}$ \\
\hline Dotcom dummy & & $\begin{array}{l}\text { Dummy variable, coded ' } 1 \text { ' for pure } \\
\text { Internet business, ' } 0 \text { ' otherwise }\end{array}$ \\
\hline
\end{tabular}

$$
\begin{aligned}
\log (\text { pre-money valuation of a new venture })=\alpha & \left.+\beta_{1} \text { (Adsales }\right) \\
& +\beta_{2}(\mathrm{R} \& \mathrm{D} \text { sales }) \\
& \left.+\beta_{3} \text { (Industry growth }\right) \\
& +\beta_{4}(\text { Industry experience }) \\
& \left.+\beta_{5} \text { (Management experience }\right) \\
& +\beta_{6}(\text { Startup experience }) \\
& \left.+\beta_{7} \text { (Team-founding }\right) \\
& +\beta_{8}(\text { Team completeness }) \\
& +\beta_{9}(\text { Network size }) \\
& +\beta_{1-k}(\text { Vector of controls })
\end{aligned}
$$




\section{T. Miloud et al.}

where $\alpha$ is the intercept, $\beta_{1}-\beta_{9}$ are the coefficients of the theoretical variables to be estimated, $\beta_{1-k}$ represent the coefficients of the control variables to be estimated, where $k$ equals to 6 . Substantial firms received multiple early-stage financings in the sample, with a minimum of one and maximum of four. Including repeated observations on the same firm in the regression model is likely to violate the standard assumption of independence from observation to observation in regression models. The interdependence of observations may lead to firm-specific heteroscedasticity and autocorrelation. If these problems exist, the coefficients estimated by ordinary least square (OLS) are inefficient. We went through two procedures to diagnose any potential violations of the classic assumptions. To diagnose potential heteroscedasticity problem, we follow Greene (2007) and examine the data by the Modified Wald test for heteroscedasticity. The results show that the variances of the dependent variables are not constant (heteroscedastic) across panels. To correct this heteroscedasticity problem, we estimate the model with random-effect OLS estimator, assuming heteroscedasticity across panels. By choosing a generalized least square (GLS) estimator with assumed heteroscedasticity, the variances of the error terms are allowed to vary from panel to panel and the effects of those contemporaneous variances are taken into account in the intercept term. To ensure that we make a correct choice of the random-effect estimator, we also conduct a Hausman specification test and the result confirms that random-effects model is appropriate for our data. Finally, we use the Breusch-Godfrey Lagrange multiple test to detect possible autocorrelation problem. The result indicates that there is no serious autocorrelation in the error terms, probably because the time waves are quite limited.

Table 2 reports the means, standard deviations and minimum and maximum of all variables used in the model. The 102 new ventures received a total of 184 rounds of early-stage venture capital financing during the sampling period. There is sufficient variability among all the variables in the model. The average valuation of the young firms across all financing rounds is around $€ 6.4$ million. The average firm

Table 2. Descriptive statistics.

\begin{tabular}{lccrr}
\hline Variable & \multicolumn{1}{c}{ Mean } & \multicolumn{1}{c}{ SD } & \multicolumn{1}{c}{ Min } & \multicolumn{1}{c}{ Max } \\
\hline Log (pre-money valuation) & 3.804 & 0.511 & 2.107 & 5.294 \\
Advertising intensity & 3.694 & 2.562 & 0.180 & 11.700 \\
R\&D intensity & 17.896 & 9.229 & 0.000 & 49.546 \\
Industry growth & 41.143 & 31.466 & -29.350 & 221.915 \\
Industry experiences & 0.932 & 0.252 & 0.000 & 1.000 \\
Management experiences & 0.618 & 0.487 & 0.000 & 1.000 \\
Startup experiences & 0.456 & 0.499 & 0.000 & 1.000 \\
Team-founding & 0.750 & 0.434 & 0.000 & 1.000 \\
Team completeness & 0.250 & 0.434 & 0.000 & 1.000 \\
Network size & 0.479 & 0.843 & 0.000 & 8.000 \\
Market size & $85,570.7$ & $135,476.1$ & $3,010.0$ & $817,223.8$ \\
ROI & -3.378 & 16.181 & -54.329 & 77.864 \\
SBF 250 index & 3597.6 & 475.7 & 2709.1 & 4354.4 \\
Firm age & 15.459 & 13.645 & 3.000 & 84.000 \\
Firm stage & 0.415 & 0.853 & -1.000 & 1.000 \\
Dotcom dummy & 0.229 & 0.421 & 0.000 & 1.000 \\
\hline
\end{tabular}


age at the financing round is around 15 months, with a minimum of 3 months and maximum of 84 months. The increased magnitude of team-based founding activities indicates increased complexity and competition over the last decade. While most founders have had relevant experiences in related industry $(93 \%)$ and executive management positions $(62 \%)$ before founding their current firm by the time of financing, only $25 \%$ of the sample firms have a complete TMT at the financing round.

\section{Results and discussion}

\section{Main statistical results}

The Appendix reports the bivariate correlation matrix of the variables used in the model. The bivariate correlations between the dependent variable and a number of independent variables are largely consistent with the theoretical predictions. Five of the nine theoretical variables are significant at $1 \%$ and in the predicted direction. The matrix also indicates that some of the independent variables are significantly correlated, but significant correlation between individual variables does not necessarily mean severe multicollinearity for the whole model. Indeed, the average variance inflating factor (VIF) of the model is only 1.23 , which is far below the conventional threshold level of 20. Thus, in this case, according to Kutner, Nachtsheim, and Neter (2004), there is no multicollinearity problem in the data.

Table 3 reports the estimates from the random-effects GLS estimation on premoney valuation of the new ventures in the sample. The coefficients are obtained after correcting heteroscedasticity across panels and controlling some confounding effects.

Model 1 is the baseline model, which contains the control variables only. Model 2 tests the industry structure effects, Model 3 tests the firm resources effects and Model 4 tests the effects of external network. Model 5 is the full model, containing all the variables. Except a small variability, the estimates are quite consistent across all the models. Therefore, we report the results mainly from the full model.

Since our primary interest at this stage of the study is to establish a theoretical linkage (and substantiate it with empirical evidences) between venture capitalists' valuation of a new venture and the theoretical variables derived from the theoretical framework, not to estimate the exact quantitative coefficients of these variables, we focus our discussion on the general relationships, not on individual coefficients.

\section{Industry structure effects}

By employing the industry organization perspective of industry stricture on firm performance, we proposed that venture capitalists consider the characteristics of industry structure when setting a value to a new venture. We include three measurements of the two industry structural variables to capture the industry structural effects on new venture valuation and each of them are hypothesized to be positively related to pre-money valuation of a new venture. Consistently, both measures of product differentiation ( $R \& D$ intensity ratio and advertising intensity) are highly significant and in the predicted direction. The results show that new ventures in highly differentiated industries (both perceptual and innovative differentiations) do receive higher valuation from venture capitalists. Thus, $H_{1}$ receives support in both Model 2 and Model 4. $\mathrm{H}_{2}$ hypothesizes that industry growth 


\section{T. Miloud et al.}

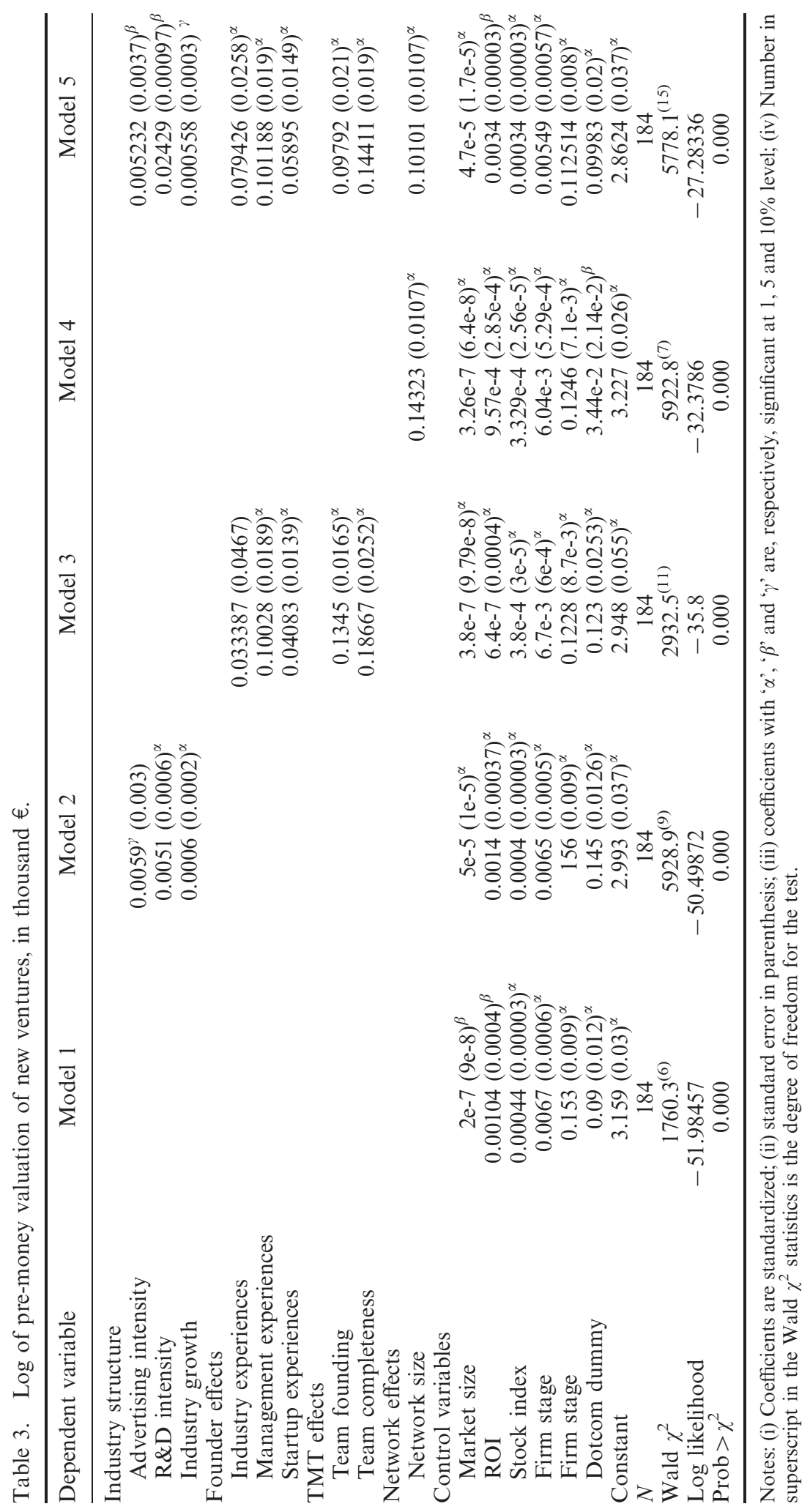


should be positively related to the valuation of new ventures by venture capitalists. As predicted, results from Model 2 and Model 4 confirm that the industry growth is indeed positively and significantly related to the pre-money valuation of new ventures. These results render strong support for the hypothesis that industry structure partially determines the startup valuation by venture capitalists. They are also consistent with McDougall, Robinson and DeNisi's (1992) study which concluded that the industry structure influences the performance of new businesses and the Zider's (1998) finding that venture capitalists give higher valuation to new ventures in growing industries.

\section{Entrepreneurial resources}

Subsequently, we hypothesized that venture capitalists consider the characteristics of the founder(s) and his management team when valuating a new venture. More specifically, we proposed that the quality of the entrepreneur and the entrepreneurial team should be positively related to the valuation of his new venture. Consistent with the theoretical prediction, all the five subhypotheses about the founder/entrepreneur and his top management receive strong support.

In terms of founder experiences, the results show that venture capitalists value a new venture significantly higher if its founder(s) has (i) relevant industry experience $\left(H_{3}\right)$, (ii) relevant managerial experiences $\left(H_{4}\right)$ and (iii) startup experiences $\left(H_{5}\right)$ before he founded his current new venture than those without such valuable experiences. Thus, all hypotheses on the three important experiences measuring the quality of the founder received strong support. The only exception is for 'industry experiences' in Model 3 with a significance level around $10 \%$, but this may also be due to a change in the covariance structure in the model.

Regarding the hypotheses on entrepreneurial team, new ventures with a complete management team are valued significantly higher than those without one $\left(H_{7}\right)$, so are new venture founded by a team of entrepreneurs rather than a solo founder $\left(H_{3}\right)$. Hence, these findings give strong overall support for proposed relationship that the characteristics of the entrepreneurial team influence new firm valuation. These findings are also consistent with those from the venture capitalist screening and selection literature that focuses on the ' $\mathrm{GO} / \mathrm{NO}-\mathrm{GO}$ ' decision (MacMillan, Siegel, and Narasimha Subba 1985; Zacharakis and Meyer 1998) as well as Franke et al. (2008) that find experience at the individual level, the existence of an entrepreneurial team, the qualifications of team members, the completeness of the team and its cohesion are important criteria for venture capitalists' valuation.

\section{External ties}

Consistent with previous findings of Stuart, Hoang, and Hybels (1999) on the public stock market's valuation of new ventures on the IPO market, the size of the new venture's network (as measured by the number of alliance partners) is significantly and positively related to its valuation by venture capitalists. This finding supports $H_{8}$ and is consistent with the literature on the benefits of alliances, particularly with the work of Zheng, Liu, and George (2010) showing that the inter-organizational network of a startup, in conjunction with its ability to innovate, influence its performance and its assessment by venture capitalists. 


\section{T. Miloud et al.}

It is worth noting that the above results are obtained after controlling for potential confounding effects of other factors from financial market, industry and firm age, stage of development and whether the new venture is a dotcom, all of which are highly significantly related to the valuation and in the positive direction.

\section{Relative importance of the theoretical perspectives}

As discussed in section 5.1 at the beginning of this section, repeated observations over the same firm excludes the use of OLS estimator to estimate the models. To overcome the heteroscedasticity arisen from repeated observations, we use a random-effect GLS estimator to estimate the models. While the GLS estimator is more efficient and has other benefits, one of the drawbacks of the GLS model is that it only reports the Wald Chi-squared test as an indicator of the model's overall fit. It does not report the $R$-squared coefficient. Thus, we cannot determine the relative explanatory power of the models by just looking at the magnitude of the overall model statistics. Fortunately, a little exploration helps solve this challenge. We know Chi-squared distribution is the sum of $n$-squared standard normal distributions, where $n$ is the number of degrees of freedom. Like the standard normal distribution, the Chi-squared distribution has several nice features, such as additivity and divisibility. Following Greene (2007), a feature of particular usefulness to our task here is that the ratio of two independent Chi-squared variables has the $F$ distribution. Therefore, we can compare the relative explanatory power of two models by dividing the two Chi-squared statistics, which is an $F$ distribution. Table 4 reports the $F$ statistics.

From the $F$-statistic value in Table 4 , it is clear that there is no significant difference among the three theoretical perspectives in terms of their explaining power of new venture valuation. In other words, it seems that venture capitalists weigh these factors equally in their valuation. However, such a conclusion may be premature as the models estimated are not fully specified as many other important variables from each theoretical perspective are not included in the model.

To further explore this issue, we did another $F$-test between all the industry variables (including the three theoretical variables - differentiation and growth, and two control variables - market size and profitability) and all the firm-level variables (including all the five theoretical variables and three firm level control variables age, stage and dotcom dummy). The value of the $F$ test $-F(8 / 5)-$ is 4.6962 , with a $p$ value of 0.0526 , which indicates that the difference is still only marginally significant. Therefore, the relative importance of the respective theoretical perspectives is not conclusive at this stage.

Table 4. Relative importance of the theoretical perspectives.

\begin{tabular}{lccc}
\hline & Industry structure & Founder/team & Network \\
\hline Wald $\chi^{2}$ & 5928.94 & 2932.5 & 5922.8 \\
Degree of freedom & 9 & 11 & 7 \\
& Industry organization/ & Resource-based & Network/industry \\
& resource-based view & view/network & organization \\
$F$-statistic & 2.021803922 & 0.495120551 & 0.9989644 \\
$p$-value & 0.1349 & 0.857 & 0.4885 \\
\hline
\end{tabular}


Regardless of the relevant importance of the three perspectives, we conclude that all three dimensions of strategic variables - industry, entrepreneurial resources and network - contribute positively to firm valuation by the investor. These findings imply that there exists an alternative route to startup valuation through an assessment of easily observable strategic variables and render the valuation process less dependent of unreliable financial calculations. Even this is a strong finding based on data from actual valuations by venture capitalists, further research is required in order to turn these findings into viable practical tools for entrepreneurs and investors.

\section{Implications for management and limitations}

Our findings suggest several implications for entrepreneurs and investors. Firstly, compared with the venture capital valuation practice, the proposed approach may lead to the development of a more accurate method for valuating new ventures. Barry $(1994,3)$ finds that more than one-third of the investments made by venture capitalists result in tosses and a sizeable fraction results in total loss of the entire original investment 'often after years of waiting and countless hours of handholding by the venture capitalists'. Moreover, over-valuation of investment deals contributed greatly to the gigantic loss during the 'dotcom bubble'. More accurate valuation methods can help mitigate this investment 'herding' and over-valuation problems in the venture capital industry.

Secondly, as illustrated by Gompers (1999), the venture capital method is essentially an internal-oriented, 'rule of thumb' method, which is inaccurate and unjustifiable. Unjustifiable low valuation is one of the major sources of venture capitalist-entrepreneur conflict. The proposed approach may help venture capitalists improve both accuracy and defensibility of their valuation and thereby facilitate VCentrepreneur collaboration and improve productivity as entrepreneurs are better able to adapt their business plan and actual operations to the requirements of venture capital investors. One of the major strengths of our approach is that it is based on input that is readily available at the time of the negotiations. Therefore, the proposed approach can not only increase accuracy and soundness of the valuation, but it is also likely to facilitate collaboration and reduce conflict between entrepreneurs and venture capitalists (Zacharakis, Erikson, and Bradley 2010). Entrepreneurs will be able to produce the required information and to understand the way venture capitalists use the information. Furthermore, a more accurate valuation of an investment target can also help the venture capitalists to defend their decisions in cases of litigation by general partners or other stakeholders.

This study uses an exploratory approach and the objective is to understand the influence of explanatory variables identified in the strategic management literature from the three fields of research on the valuation of startups. However, the study also presents some limitations inherent to this approach. First, our theoretical approach takes into consideration the complementarity of the industrial economics field, the resource-based view and the network approach. One weakness of this study is that it is limited to a few variables from these areas of research. Especially, variables from the network literature could extend the model developed in this article. There are also other dimensions of variables that should be considered to be entered into the model. One interesting venue would be to incorporate the characteristics and cognitive abilities of venture capitalists, although such 
information would be difficult to find and operationalize. Another promising venue with less methodological issues would be to incorporate technology variables. We know from previous research that new ventures with different technologies face different challenges in terms of market entry and that it influences their profit potential and ability to survive (Aspelund, Berg-Utby, and Skjevdal 2005). All these effects are well known by venture capitalists and it is likely that they are taken under consideration in new venture valuations. Finally, our study is limited in terms of its time period and country (France).

Hence, multiple paths exist to extend this strand of research on new venture valuation: (i) test our model on a new startup through a clinical study incorporating more network effects, technological and venture capitalist characteristics, (ii) conduct an exploratory study to know all the limitations of the model, (iii) the use in combination approach for real options and strategic approach for the evaluation of a startup and (iv) extend the observation period and have a sample of European startups in order to broader conduct a study comparative.

\section{Conclusions}

How to value a company is traditionally a finance topic; however, most financial valuation methods were developed for well-established companies and especially for companies in the more efficient public capital market. As demonstrated by Waldron and Hubbard (1991), the traditional financial methods yield valuations with large variability. Against such a backdrop, this article leverages established theories in strategic management to develop an integrated framework and use those input variables important to firm performance to directly predict the valuation of an earlystage new venture. Presumably, when it is difficult to value a young firm based on output (e.g. future cash-flows), pricing it based on inputs (e.g. entrepreneur, industry attractiveness, etc.) may be a better alternative than 'pure guess'. Though tentative, the results from the empirical analyses support the central propositions that strategic management theories are useful in explaining the valuation of early-stage new ventures. This empirically substantiated linkage between established strategy theories and new venture valuation practice makes it possible to develop a systematic approach to identify and measure factors important to new venture valuation. Such findings hold a lot of promise for both theory building and practice in entrepreneurial financing.

For Dittmann, Maug, and Kemper (2004), the use of multiple valuation methods significantly reduces the failure rate of funding agreements between venture capitalists and entrepreneurs. Venture capital investors that base their investment strategy on core business values and adopt a long-term vision seem to have an advantage over those who engage in short-term subjective bargaining strategies. The use of valuation criteria from the strategic management provides a long-term vision of both the venture and of the funding provided after the venture valuation.

Gompers and Lerner (1999) argue that the venture capital has been an important factor behind both entrepreneurship and innovation in US economy for the past 30 years. Despite its critical importance in venture capital financing, how to value a new venture is seldom touched in the extant literature and only a handful papers are available. Moreover, even the few existing studies are clinical and descriptive in nature. This study goes beyond simple descriptive statistics and fills this noted gap in the research literature. We leverage well-established theories in strategic 
management to develop an integrated framework to study new venture valuation by venture capitalists. Extending the axiom definition of investment value in the finance literature that the economic value of any asset is the value of its future cash flows, which is the measure of firm performance, we propose that those factors that have been identified as important to firm performance in the strategic management literature should be positively related to the valuation of a new venture. Therefore, venture capitalists should take these factors into consideration when they value a new venture in their investment decision process.

From this central proposition and grounded in the three mainstream strategy theories, eight hypotheses were developed on the effects of industry structure, founder and TMT, and external relationships of a new venture on its valuation by venture capitalists. Robust statistical analyses based on a large sample of 184 earlystage financing rounds on 102 new ventures provide support for almost all of the hypotheses, which indicate that the strategic management theories are indeed useful to explain venture capitalists' valuation of early-stage new ventures. This empirically supported linkage between strategic management theories and new venture valuation practice should hold some promise for exploring complementary valuation methods for new ventures, especially when traditional valuation approaches are not reliable due to lack of accounting information.

\section{References}

Aspelund, A., T. Berg-Utby, and R. Skjevdal. 2005. Initial resources' influence on new venture survival: A longitudinal study of new technology-based firms. Technovation 25: 1337-47.

Barry, C. 1994. New directions in research on venture capital finance. Financial Management 23: 3-15.

Baum, J., T. Calabrese, and B. Silverman. 2000. Don't go it alone: Alliance network composition and startups' performance in Canadian biotechnology. Strategic Management Journal 21: 267-94.

Brealey, R., S. Myers, and F. Allen. 2007. Principles of corporate finance. New York: McGraw Hill Higher Education.

Carpenter, M., and J. Fredrickson. 2001. Top management teams, global strategic posture and the moderating role of uncertainty. Academy of Management Journal 44: 533-45.

Caves, R.E. 1972. American industry: Structure, conduct, and performance. Englewood Cliffs, NJ: Prentice Hall.

Clercq, D., H. Fried, O. Lehtonen, and H. Sapienza. 2006. An entrepreneur's guide to the venture capital galaxy. Academy of Management Perspectives 20: 90-112.

Comanor, W., and T. Wilson. 1967. Advertising, market structure, and performance. Review of Economies and Statistics 49: 423-40.

Deeds, D., and C. Hill. 1996. Strategic alliances and the rate of new product development: An empirical study of entrepreneurial biotechnology firms. Journal of Business Venturing 11: $107-32$.

Dittmann, I., E. Maug, and J. Kemper. 2004. How fundamental are fundamental values? Valuation methods and their impact on the performance of German venture capitalists. European Financial Management 10: 609-38.

Dubini, P., and H. Aldrich. 1991. Personal and extended networks are central to the entrepreneurial process. Journal of Business Venturing 6: 305-13.

Eisenhardt, K., and C. Schoonhoven. 1990. Organizational growth: Linking founding team, strategy, environment and growth among us semiconductor ventures, 1978-1988. Administrative Science Quarterly 35: 504-29.

Eisenhardt, K., and C. Schoonhoven. 1996. Resource-based view of strategic alliance formation: Strategic and social effects in entrepreneurial firms. Organization Science 7: $136-50$. 


\section{T. Miloud et al.}

Franke, N., M. Gruber, D. Harhoff, and J. Henkel. 2008. Venture capitalists' evaluations of start-up teams: Trade-offs, knock-out criteria, and the impact of $\mathrm{VC}$ experience. Entrepreneurship Theory and Practice 32: 459-83.

Gimeno, J., T. Folta, and A. Cooper. 1997. Survival of the fittest? Entrepreneurial human capital and the persistence of underperforming firms. Administrative Science Quarterly 42: $750-83$.

Gompers, P. 1995. Optimal investment, monitoring, and the staging of venture capital. Journal of Finance 50: 1461-89.

Gompers, P. 1999. A note on valuation in entrepreneurial ventures. Harvard Business School Case 9298082: 1-17.

Gompers, P., and J. Lerner. 1999. Conflict of interest in the issuance of public securities: Evidence from venture capital. Journal of Law \& Economics 42: 1-28.

Greene, W. 2007. Econometric analysis. 6th ed. Englewood Cliffs, NJ: Prentice Hall.

Gulati, R. 1995. Social structure and alliance formation patterns: A longitudinal analysis. Administrative Science Quarterly 40: 619-52.

Hall, J., and C. Hofer. 1993. Venture capitalists' decision criteria in new venture evaluation. Journal of Business Venturing 8: 25-42.

Hall, M., and L. Weiss. 1967. Firm size and profitability. The Review of Economics and Statistics XLIX: 319-31.

Hansen, E. 1995. Entrepreneurial network and new organization growth. Entrepreneurship: Theory \& practice 19: 395-412.

Hoang, H., and B. Antoncic. 2002. Network-based research in entrepreneurship: A critical review. Journal of Business Venturing 17: 1-23.

Kutner, M., C. Nachtsheim, and J. Neter. 2004. Applied linear statistical models. 5th ed. New York: McGraw-Hill/Irwin.

Larson, A., and J. Starr. 1993. A network model of organization formation. Entrepreneurship: Theory \& Practice 17: 5-15.

Lee, C., K. Lee, and J. Pennings. 2001. Internal capabilities, external networks, and performance: A study on technology-based ventures. Strategic Management Journal 22: 615-40.

Lerner, J. 1994. The syndication of venture capital investments. Financial Management 23: 1627.

Lerner, J. 1995. Venture capitalists and the oversight of private firms. Journal of Finance L: $301-18$.

Levie, J., and E. Gimmon. 2008. Mixed signals: Why investors may misjudge first time high technology venture founders. Venture Capital 10: 233-56.

MacMillan, I., R. Siegel, and P.N. Narasimha Subba. 1985. Criteria used by venture capitalists to evaluate new venture proposals. Journal of Business Venturing 1: 119-28.

McDougall, P., R. Robinson, and A. DeNisi. 1992. Modeling new venture performance: An analysis of new venture strategy, industry structure, and venture origin. Journal of Business Venturing 7: 267-89.

Muzyka, D., S. Birley, and B. Leleux. 1996. Trade-offs in the investment decisions of European venture capitalists. Journal of Business Venturing 1: 273-87.

Peltzman, S. 1977. The gains and losses from industrial concentration. Journal of Law and Economics 20: 229-63.

Porter, M. 1980. Competitive strategy: Techniques for analyzing industries and competitors. New York: Free Press.

Roure, J., and R. Keeley. 1990. Predictors of success in new technology based ventures. Journal of Business Venturing 5: 201-20.

Ruhuka, J., and J. Young. 1987. A venture capital model of the development process for new ventures. Journal of Business Venturing 2: 167-84.

Sandberg, W., and C. Hofer. 1987. Improving new venture performance: The role of strategy, industry structure, and the entrepreneur. Journal of Business Venturing 12: 11-25.

Siegel, R., E. Siegel, and I. MacMillan. 1993. Characteristics distinguishing high growth ventures. Journal of Business Venturing 8: 169-80.

Silva, J. 2004. Venture capitalists' decision-making in small equity markets: A case study using participant observation. Venture Capital 6: 125-45. 
Stuart, T., H. Hoang, and R. Hybels. 1999. Interorganizational endorsements and the performance of entrepreneurial ventures. Administrative Science Quarterly 44: 315-49.

Timmons, J. 1992. New venture creation: Entrepreneurship in the 1990s. 4th ed. New York: McGraw-Hill/Irwin.

Tushman, M., and R. Anderson. 1986. Technological discontinuities and organizational environments. Administrative Science Quarterly 31: 439-65.

Tyebjee, T., and A. Bruno. 1984. A model of venture capitalist investment activity. Management Science 30: 1051-66.

Uzzi, B. 1996. The sources and consequences of embeddedness for the economic performance of organizations: The network effect. American Sociology Review 61: 674-98.

Waldron, D., and C. Hubbard. 1991. Valuation methods and estimates in relationship to investing versus consulting. Entrepreneurship: Theory \& practice 16: 43-52.

Zacharakis, A., and G. Meyer. 1998. A lack of insight: Do venture capitalists really understand their own decision process? Journal of Business Venturing 13: 57-76.

Zacharakis, A., T. Erikson, and G. Bradley. 2010. Conflict between the VC and entrepreneur: The entrepreneurs' perspective. Venture Capital 12: 109-26.

Zheng, Y., J. Liu, and G. George. 2010. The dynamic impact of innovative capability and inter-firm network on firm valuation: A longitudinal study of biotechnology start-ups. Journal of Business Venturing 25: 593-609.

Zider, B. 1998. How venture capital works. Harvard Business Review 76: 131-9.

Zimmerman, A. 2008. The influence of top management team heterogeneity on the capital raised through an initial public offering. Entrepreneurship Theory and Practice 32: 391414. 


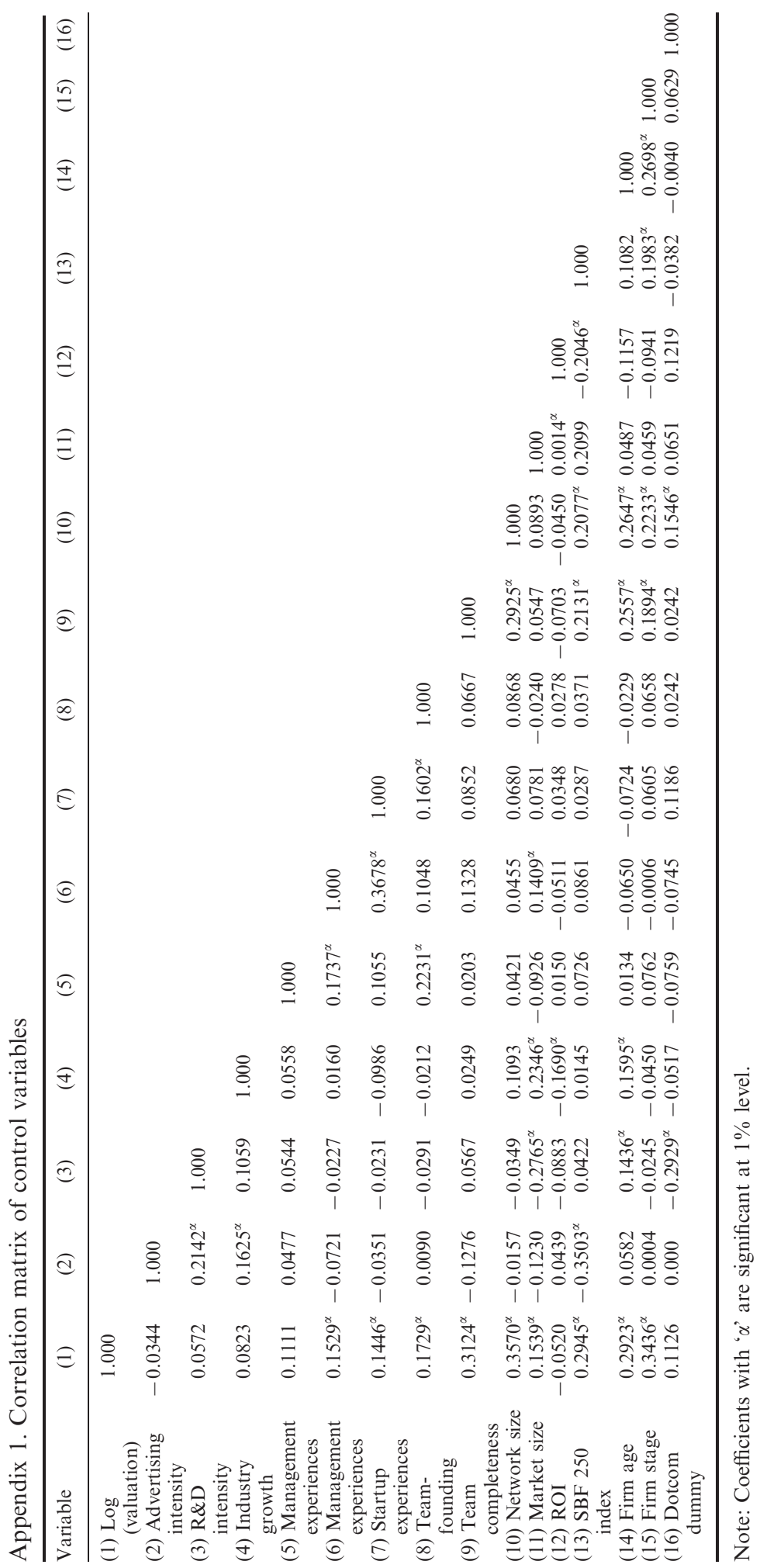

